\title{
Study of the surface hardness and modulus of elasticity of conventional and microwave-cured acrylic resins
}

\begin{abstract}
Márcio José Fraxino Bindo(a) Atlas Edson Moleros Nakamae (b) Lydia de Brito Santos ${ }^{(c)}$ Karin Hitomi Ishikawa(d) Tatiana de Carvalho Guarnieri(e) Regina Tamaki ${ }^{(b)}$
\end{abstract}

(a) Professor, Department of Prosthodontics, School of Dentistry, Federal University of Paraná.

(b) Professor; (d)DDS; (e)PhD - Department of Prosthodontics, School of Dentistry, University of São Paulo.

(c) Professor, Department of Prosthodontics, School of Dentistry, State University of Feira de Santana.

Corresponding author:

Atlas Edson Moleros Nakamae

Departamento de Prótese

Faculdade de Odontologia da USP

Av. Prof. Lineu Prestes, 2227

Cidade Universitária

São Paulo - SP - Brazil

CEP: 05508-000

E-mail:atlas@usp.br
Abstract: The aim of this study was to evaluate the following acrylic resins: Clássico ${ }^{\circledR}, \mathrm{QC}-20^{\circledR}$ and Lucitone ${ }^{\circledR}$, recommended specifically for thermal polymerization, and Acron $\mathrm{MC}^{\circledR}$ and VIPI-WAVE ${ }^{\circledR}$, made for polymerization by microwave energy. The resins were evaluated regarding their surface nanohardness and modulus of elasticity, while varying the polymerization time recommended by the manufacturer. They were also compared as to the presence of water absorbed by the samples. The technique used was nanoindentation, using the Nano Indenter $\mathrm{XP}^{\circledR}$, MTS. According to an intra-group analysis, when using the polymerization time recommended by the manufacturer, a variation of 0.14 to 0.23 GPa for nanohardness and 2.61 to $3.73 \mathrm{GPa}$ for modulus of elasticity was observed for the thermally polymerized resins. The variation for the resins made for polymerization by microwave energy was 0.15 to 0.22 GPa for nanohardness and 2.94 to $3.73 \mathrm{GPa}$ for modulus of elasticity. The conclusion was that the Classico ${ }^{\circledR}$ resin presented higher nanohardness and higher modulus of elasticity values when compared to those of the same group, while Acron $\mathrm{MC}^{\circledR}$ presented the highest values for the same characteristics when compared to those of the same group. The water absorption evaluation showed that all the thermal polymerization resins, except for Lucitone ${ }^{\circledR}$, presented significant nanohardness differences when submitted to dehydration or rehydration, while only Acron $\mathrm{MC}^{\circledR}$ presented no significant differences when submitted to a double polymerization time. Regarding the modulus of elasticity, it was observed that all the tested materials and products, except for Lucitone ${ }^{\circledR}$, showed a significant increase in modulus of elasticity when submitted to a lack of hydration.

Descriptors: Denture, complete; Polymethyl methacrylate; Hardness; Elasticity. 


\section{Introduction}

For many decades, polymethylmethacrylate has been the first choice for making the base of complete dentures. Thermally activated acrylic resins have been traditionally processed by immersion in temperature-controlled water, for a specific period of time. ${ }^{1}$ Recently, polymerization methods involving activated light and microwave energy were introduced.

In the last years, many studies have been carried out in order to improve the physical and mechanical properties of the acrylic resins activated by microwave energy. ${ }^{1-6}$ The heating by microwave energy is independent on thermal conductivity. When dielectric materials are placed in a microwave energy field, some kind of molecular friction takes place and these materials warm up rapidly. ${ }^{3}$ Some authors believe that physical proprieties such as hardness and transversal resistance are favored when this process polymerizes the resins, ${ }^{4}$ others believe that the polymerization by immersion in heated water during a long cycle results in better physical properties. ${ }^{2}$ Others still consider that the conventional and microwave energy methods are similar, such as Smith et al. ${ }^{5}$ (1992), who submitted some materials to the existing polymerization methods: conventional (water heat diffusion), microwave energy and light, and then compared properties such as hardness, surface smoothness, transversal resistance, modulus of elasticity and resistance to impact. The only difference found between the two methods was that the second showed higher values for modulus of elasticity.

When the physical properties of the acrylic resins are highlighted, many are the elements that can vary inside its structure, either cooping or creating obstacles that are liable to interfere with the material's ultimate rate of success. Among these elements we can point out the modulus of elasticity, which is directly related to the material's resistance to flexion, nanohardness, and also the loss modulus and fluidity, which are related to the material's viscosity and therefore with the probability of it suffering fractures or permanent deformations. ${ }^{1}$

In the present study the surface nanohardness and the modulus of elasticity versus variations on the polymerization time recommended by the manufacturer of five acrylic resins broadly used for the base of complete dentures were studied. The same characteristics were evaluated when the materials were submitted to a lack of hydration followed by rehydration.

\section{Material and Methods Manufacture of the samples made of resin polymerized by a thermal procedure}

To manufacture the samples, glass slides measuring $10 \mathrm{~mm} \times 10 \mathrm{~mm} \times 2 \mathrm{~mm}$ were used. $100 \mathrm{~g}$ of Herodent $^{\circledR}$ type IV dental stone (Vigodent, Rio de Janeiro, $\mathrm{RJ}$, Brazil) were mixed to $24 \mathrm{ml}$ of distillated water, which was then poured into a copper muffle used for conventional polymerization of resins, previously isolated with vaseline. The glass slides were then embedded in the muffle, and after the time recommended by the stone manufacturer for its complete crystallization, the same muffle was adapted to the counter muffle, which was completely filled with a new portion of stone. After its complete crystallization, the muffle was opened and the glass slides were removed.

The monomer and the polymer of the Clássico ${ }^{\circledR}$ resin (Clássico Artigos Odontológicos Ltda., São Paulo, SP, Brazil) were then mixed according to the proportion recommended by the manufacturer. When the mix reached the working phase, the material was embedded in the muffle. This way, faithful

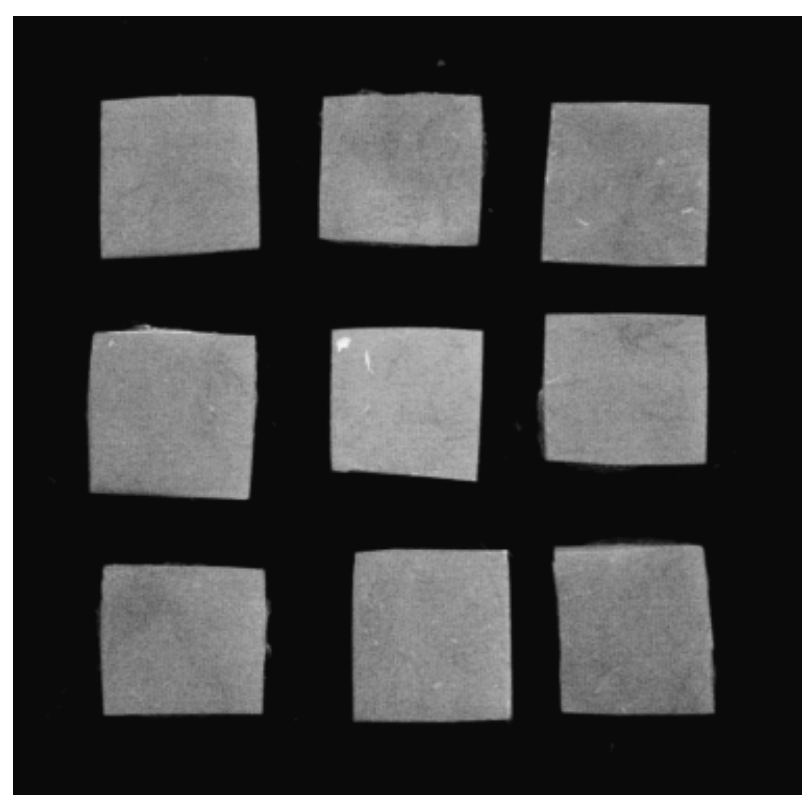

Figure 1 - Resin samples made for the readings. 
copies of the samples were produced in resin (Figure 1). The force applied to close the muffle was $1,250 \mathrm{kgf}$, maintained by a hydraulic press.

The whole set rested for 4 hours and after that the polymerization cycle started. This was made inside an electrical polymerizing machine, with temperature regulated at $74^{\circ} \mathrm{C}$, for 9 hours. After the resin was polymerized and the muffle cooled off, the sample bars were removed and polished with alumina, in order to obtain flat and smooth surfaces.

Identical procedures were performed in order to obtain samples of the resins Lucitone ${ }^{\circledR}$ (Dentsply Indústria e Comércio Ltda., Petrópolis, RJ, Brazil) and QC-20 ${ }^{\circledR}$ (Dentsply Indústria e Comércio Ltda., Petrópolis, RJ, Brazil).

\section{Manufacture of the resin samples polymerized by microwave energy}

Once more a muffle was used in order to polymerize the resin samples. These muffles were now made of reinforced glass fiber (Figure 2), especially made for use in microwave ovens. Following the same technique as that used to obtain the samples of the previous resins, glass slides were then included in the muffles. The same Herodent ${ }^{\circledR}$ type IV dental stone was used.

The first resin to be manipulated was Acron $\mathrm{MC}^{\circledR}$ (GC Lab Technologies Inc., Alsip, IL, USA), following the manufacturer's instructions, and when the

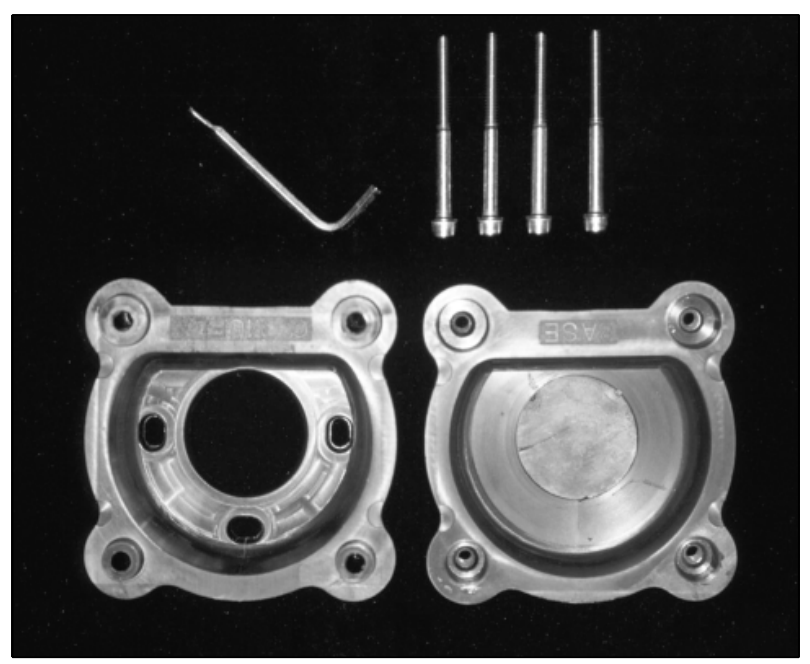

Figure 2 - Fiberglass muffle (GC brand, Dental Industrial Corporation) proper for microwave use. mix reached the working phase it was embedded in the muffle, which was closed with the aid of screws. The force used for closing was 1,250 kgf.

After waiting 15 minutes the whole set was placed inside a Sharp ${ }^{\circledR}$ microwave oven, on the center of the plate, and was irradiated for 3 minutes, with $500 \mathrm{~W}$ of power. A 20 minutes break was taken and the muffle was washed with cool water on the outside. After 20 more minutes its complete cooling was checked and only then the samples were removed from its interior. The same procedure for polishing described for the previous group was carried out.

Three different groups of samples were obtained. One of them was polymerized following exactly the time and procedures recommended by the manufacturer. The other two were polymerized with twice and half of the polymerization time recommended, respectively, for the Acron $\mathrm{MC}^{\circledR}$ resin.

These procedures were repeated for the VIPIWAVE $^{\circledR}$ resin (VIPI Ltda., Pirassununga, SP, Brazil) according to the manufacturer's recommendations, which state that the mixture should be taken to a microwave oven with $900 \mathrm{~W}$ of power, and be irradiated with $40 \%$ of the power for 2 minutes, and then rest for 15 minutes. After the resting period, they should be irradiated again with $20 \%$ of the power for 8 minutes, and finally for 3 minutes with $60 \%$ of the power. This way, a standard group was obtained, polymerized by following precisely the manufacturer's directions. Another two groups were irradiated, respectively, with twice as much time and half of the time recommended.

All the samples were always kept immersed in distillated water.

\section{Resin samples analysis and reading}

To read the samples a nanoindentation device named Nano Indenter XP (MTS Nano Instruments, Oak-Ridge, TN, USA) was used. This device is made of three different parts: a penetrating cylinder head, an optical microscope and a mobile table (Figure 3).

The samples were placed inside the device in order to be read, following a time schedule according to the type of resin obtained and the polymerization time used for each polymerization (Figure 4).

Before all the analyses were done, the behavior 


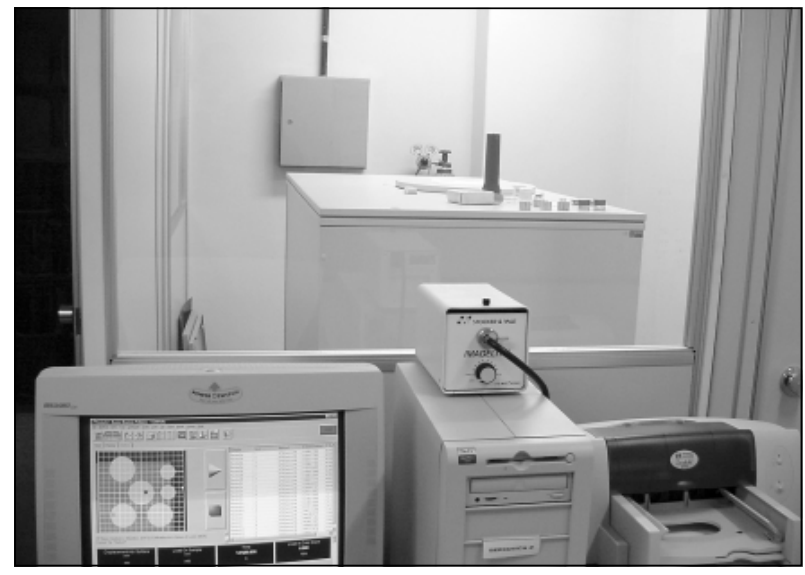

Figure 3 - Assessment device of the Nano Indenter XP.

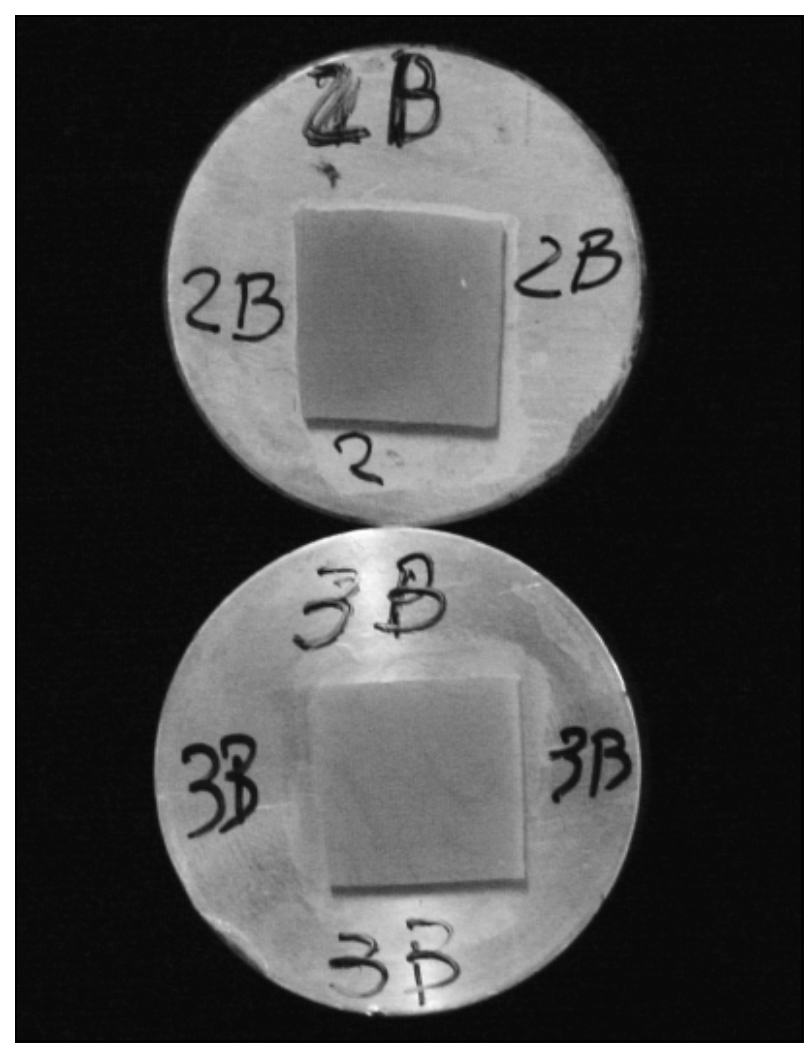

Figure 4 - Samples made for the measurements.

of the resins was observed after the first reading, and after 7 days of dehydration, after which a complete set of readings was performed. This was called the $2^{\text {nd }}$ reading. The samples were then rehydrated for another 7 days, and then the $3^{\text {rd }}$ reading was performed inside the Nano Indenter XP ${ }^{\circledR}$.

All the readings in this study were accomplished by 8 loads of indentations, each one of them having a set of approximately 13 readings, completing an average of one hundred reading tests for each sample total, going from zero to 7 thousand nanometers of depth.

\section{Results}

As we analyzed the nanohardness of the conventional, thermally polymerized resins, which were polymerized according to the recommendations of the manufacturer, it was observed that the Clássico resin presented a significant difference when compared to QC-20 ${ }^{\circledR}$ and Lucitone ${ }^{\circledR}$, which were very similar to each other (Table 1).

The same occurred to these materials when considering their modulus of elasticity (Table 2).

The group of resins that were polymerized by microwave energy according to the standard time of polymerization presented significant differences. Acron $\mathrm{MC}^{\circledR}$ presented higher nanohardness and modulus of elasticity values than VIPI-WAVE ${ }^{\circledR}$ (Table 1).

When comparing the two groups submitted to different polymerization methods, it was observed that there was a similarity of results, both regarding nanohardness and modulus of elasticity, especially when comparing Acron $\mathrm{MC}^{\circledR}$ and Clássico, and VIPI-WAVE ${ }^{\circledR}$ and QC-20 ${ }^{\circledR} /$ Lucitone $^{\circledR}$.

Regarding the values of modulus of elasticity versus variations in the polymerization time, it was observed that, for Acron $\mathrm{MC}^{\circledR}$, as this time decreased, the modulus of elasticity also decreased, and when the time was doubled, the modulus of elasticity also showed an increase, although keeping a level which was similar to that obtained with the standard polymerization time.

The VIPI-WAVE ${ }^{\circledR}$ resin presented an increase in modulus of elasticity when compared to that obtained when the standard polymerization was performed (according to the manufacturer's recommendations), both with half of the polymerization time and with the polymerization time doubled.

Regarding the resins' behavior when submitted to a lack of hydration ( $2^{\text {nd }}$ reading), and to an ensuing rehydration ( $3^{\text {rd }}$ reading), it was observed that in the conventional thermal polymerization group, the values for nanohardness were very similar when us- 
Table 1 - Descriptive statistics for type of material / Hardness (GPa).

\begin{tabular}{|c|c|c|c|c|c|c|c|c|}
\hline \multicolumn{3}{|c|}{ Data } & \multirow{2}{*}{$\begin{array}{c}\text { Average } \\
0.236\end{array}$} & \multirow{2}{*}{$\begin{array}{c}\begin{array}{c}\text { Standard } \\
\text { Deviation }\end{array} \\
0.016\end{array}$} & \multirow{2}{*}{$\begin{array}{c}\text { Minimum } \\
0.222\end{array}$} & \multirow{2}{*}{$\begin{array}{c}\text { Maximum } \\
0.264\end{array}$} & \multicolumn{2}{|c|}{ P value (1) } \\
\hline \multirow{3}{*}{\multicolumn{2}{|c|}{ Clássico ${ }^{\circledR}$}} & Standard & & & & & \multirow{3}{*}{$<0.0001$} & \multirow{3}{*}{$S$} \\
\hline & & Without water & 0.234 & 0.005 & 0.226 & 0.240 & & \\
\hline & & With water & 0.207 & 0.007 & 0.196 & 0.216 & & \\
\hline \multirow{3}{*}{\multicolumn{2}{|c|}{ Lucitone $^{\circledR}$}} & Standard & 0.156 & 0.008 & 0.147 & 0.169 & \multirow{3}{*}{0.084} & \multirow{3}{*}{ NS } \\
\hline & & Without water & 0.162 & 0.009 & 0.152 & 0.177 & & \\
\hline & & With water & 0.158 & 0.007 & 0.145 & 0.168 & & \\
\hline \multirow{3}{*}{\multicolumn{2}{|c|}{ QC-20 ${ }^{\circledR}$}} & Standard & 0.145 & 0.017 & 0.123 & 0.170 & \multirow{3}{*}{0.008} & \multirow{3}{*}{ S } \\
\hline & & Without water & 0.155 & 0.017 & 0.136 & 0.178 & & \\
\hline & & With water & 0.147 & 0.015 & 0.136 & 0.177 & & \\
\hline \multirow{9}{*}{ VIPI - WAVE ${ }^{\circledast}$} & \multirow{3}{*}{ Standard time } & Standard & 0.158 & 0.009 & 0.149 & 0.175 & \multirow{3}{*}{$<0.0001$} & \multirow{3}{*}{$\mathrm{S}$} \\
\hline & & Without water & 0.193 & 0.015 & 0.175 & 0.216 & & \\
\hline & & With water & 0.175 & 0.018 & 0.157 & 0.204 & & \\
\hline & \multirow{3}{*}{$\begin{array}{l}\text { Half the } \\
\text { Standard time }\end{array}$} & Standard & 0.255 & 0.013 & 0.241 & 0.278 & \multirow{3}{*}{$<0.0001$} & \multirow{3}{*}{$\mathrm{S}$} \\
\hline & & Without water & 0.295 & 0.035 & 0.259 & 0.350 & & \\
\hline & & With water & 0.291 & 0.028 & 0.259 & 0.338 & & \\
\hline & \multirow{3}{*}{$\begin{array}{l}\text { Twice the } \\
\text { standard time }\end{array}$} & Standard & 0.243 & 0.007 & 0.235 & 0.254 & \multirow{3}{*}{$<0.0001$} & \multirow{3}{*}{$\mathrm{S}$} \\
\hline & & Without water & 0.282 & 0.029 & 0.257 & 0.330 & & \\
\hline & & With water & 0.268 & 0.019 & 0.247 & 0.298 & & \\
\hline \multirow{9}{*}{ Acron $\mathrm{MC}^{\circledast}$} & \multirow{3}{*}{ Standard time } & Standard & 0.226 & 0.007 & 0.219 & 0.238 & \multirow{3}{*}{$<0.0001$} & \multirow{3}{*}{$\mathrm{S}$} \\
\hline & & Without water & 0.326 & 0.034 & 0.285 & 0.365 & & \\
\hline & & With water & 0.231 & 0.031 & 0.192 & 0.276 & & \\
\hline & \multirow{3}{*}{$\begin{array}{l}\text { Half the } \\
\text { Standard time }\end{array}$} & Standard & 0.191 & 0.024 & 0.167 & 0.238 & \multirow{3}{*}{$<0.0001$} & \\
\hline & & Without water & 0.198 & 0.020 & 0.177 & 0.230 & & $S$ \\
\hline & & With water & 0.169 & 0.015 & 0.149 & 0.190 & & \\
\hline & & Standard & 0.284 & 0.034 & 0.247 & 0.336 & & \\
\hline & $\begin{array}{l}\text { Iwice the } \\
\text { standard time }\end{array}$ & Without water & 0.282 & 0.010 & 0.265 & 0.298 & 0.328 & NS \\
\hline & & With water & 0.273 & 0.014 & 0.250 & 0.286 & & \\
\hline
\end{tabular}

(1) Intra-group analysis, using a parametric test (Repeated Measures ANOVA).

ing the standard time of polymerization, except for a few variations, as can be seen in Graph 1.

Yet in the group of resins polymerized by microwave energy there was a variation in nanohardness values when they were submitted to dehydration, specially for Acron $\mathrm{MC}^{\circledR}$, when they were polymerized according to the time recommended by the manufacturer. This variation, however, diminished after rehydration. The same happened to their modulus of elasticity (Graph 2).

\section{Discussion}

The resins used for the base of complete dentures are of utmost importance, since the maximum bite strength of a patient using a complete denture is approximately $1 / 6$ of that of a dentate patient. For this reason, it is very important that its adaptability, structure and especially manipulation procedures be reliable.

Currently, the focus of researchers regarding microwave energy has been the analysis of the polymerization method. Nevertheless, there is some con- 
Table 2 - Descriptive statistics for type of material / Modulus of Elasticity (GPa).

\begin{tabular}{|c|c|c|c|c|c|c|c|c|}
\hline \multicolumn{3}{|c|}{ Data } & \multirow{2}{*}{$\begin{array}{c}\text { Average } \\
3.724\end{array}$} & \multirow{2}{*}{$\begin{array}{c}\text { Standard } \\
\text { Deviation }\end{array}$} & \multirow{2}{*}{$\begin{array}{c}\text { Minimum } \\
3.591\end{array}$} & \multirow{2}{*}{$\begin{array}{c}\text { Maximum } \\
3.962\end{array}$} & \multicolumn{2}{|c|}{ P value (1) } \\
\hline \multirow{3}{*}{\multicolumn{2}{|c|}{ Clássico ${ }^{\circledR}$}} & Standard & & & & & \multirow{3}{*}{$<0.0001$} & \multirow{3}{*}{$S$} \\
\hline & & Without water & 3.709 & 0.084 & 3.628 & 3.841 & & \\
\hline & & With water & 3.466 & 0.094 & 3.350 & 3.646 & & \\
\hline \multirow{3}{*}{\multicolumn{2}{|c|}{ Lucitone $^{\circledR}$}} & Standard & 2.925 & 0.200 & 2.757 & 3.386 & \multirow{3}{*}{0.872} & \multirow{3}{*}{ NS } \\
\hline & & Without water & 2.924 & 0.061 & 2.862 & 3.044 & & \\
\hline & & With water & 2.894 & 0.072 & 2.785 & 2.983 & & \\
\hline \multirow{3}{*}{\multicolumn{2}{|c|}{ QC- $20^{\circledR}$}} & Standard & 2.613 & 0.168 & 2.415 & 2.857 & \multirow{3}{*}{0.008} & \multirow{3}{*}{$S$} \\
\hline & & Without water & 2.716 & 0.165 & 2.539 & 2.941 & & \\
\hline & & With water & 2.733 & 0.190 & 2.594 & 3.161 & & \\
\hline \multirow{9}{*}{ VIPI - WAVE ${ }^{\circledR}$} & \multirow{3}{*}{ Standard time } & Standard & 2.945 & 0.080 & 2.870 & 3.072 & \multirow{3}{*}{$<0.0001$} & \multirow{3}{*}{$S$} \\
\hline & & Without water & 3.282 & 0.095 & 3.202 & 3.467 & & \\
\hline & & With water & 3.148 & 0.154 & 2.990 & 3.412 & & \\
\hline & \multirow{3}{*}{$\begin{array}{c}\text { Half the } \\
\text { Standard time }\end{array}$} & Standard & 3.864 & 0.108 & 3.746 & 3.994 & \multirow{3}{*}{$<0.0001$} & \multirow{3}{*}{$S$} \\
\hline & & Without water & 4.128 & 0.210 & 3.883 & 4.434 & & \\
\hline & & With water & 4.217 & 0.230 & 3.991 & 4.546 & & \\
\hline & \multirow{3}{*}{$\begin{array}{l}\text { Twice the } \\
\text { standard time }\end{array}$} & Standard & 3.808 & 0.080 & 3.741 & 3.945 & \multirow{3}{*}{$<0.0001$} & \multirow{3}{*}{$\mathrm{S}$} \\
\hline & & Without water & 4.076 & 0.151 & 3.923 & 4.367 & & \\
\hline & & With water & 4.079 & 0.150 & 3.905 & 4.299 & & \\
\hline \multirow{9}{*}{ Acron $M^{\circledR}{ }^{\circledR}$} & \multirow{3}{*}{ Standard time } & Standard & 3.737 & 0.074 & 3.619 & 3.815 & \multirow{3}{*}{$<0.0001$} & \multirow{3}{*}{$\mathrm{S}$} \\
\hline & & Without water & 4.634 & 0.107 & 4.506 & 4.786 & & \\
\hline & & With water & 3.688 & 0.187 & 3.424 & 3.949 & & \\
\hline & \multirow{3}{*}{$\begin{array}{l}\text { Half the } \\
\text { Standard time }\end{array}$} & Standard & 3.135 & 0.213 & 2.859 & 3.502 & \multirow{3}{*}{$<0.0001$} & \\
\hline & & Without water & 3.246 & 0.095 & 3.129 & 3.415 & & $S$ \\
\hline & & With water & 3.030 & 0.142 & 2.870 & 3.254 & & \\
\hline & & Standard & 4.048 & 0.190 & 3.838 & 4.370 & & \\
\hline & Twice the & Without water & 4.069 & 0.081 & 3.958 & 4.214 & 0.927 & NS \\
\hline & & With water & 4.070 & 0.190 & 3.841 & 4.368 & & \\
\hline
\end{tabular}

(1) Intra-group analysis, using a parametric test (Repeated Measures ANOVA).

cern about the types of resin being used, as in the study by Kimura et al. ${ }^{3}$ (1983), who state that the resin should be carefully chosen in order to avoid fractures, or by Hayden ${ }^{7}$ (1986), who also links the type of resin to its influence on the resistance to fractures. Both, however, end up comparing the polymerization methods, using microwave energy or a conventional thermal water bath.

When varying the polymerization time, specifically when considering microwave resins, it was observed that, except for a very small variation with the Acron $\mathrm{MC}^{\circledR}$ resin when using half of the polymerization time, there was no significant difference for all the attempts, and no significant difference was observed when this time was changed, according to the depths of the samples.

These data are in accordance with the studies by Sanders et al. ${ }^{8}$ (1987), De Clerck ${ }^{9}$ (1987), Levin et al. ${ }^{10}$ (1989), Shlosberg et al. ${ }^{11}$ (1989), Ilbay et al. ${ }^{12}$ (1994), Arima et al. ${ }^{13}$ (1995), Monteiro Netto et al..$^{14}$ (1999) and their concerns regarding the resistance to fracture of the materials when submitted to 
Graph 1 - Nanohardness of the resins in all groups.

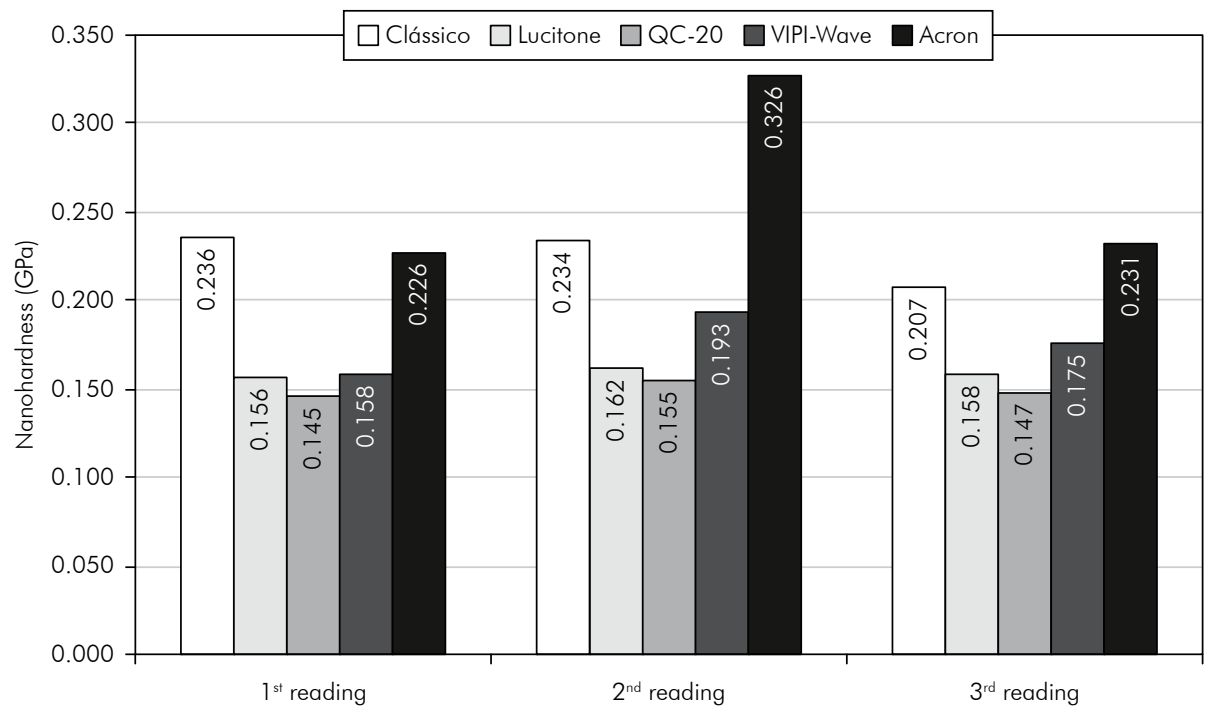

Graph 2 - Modulus of elasticity of all resins in all groups.

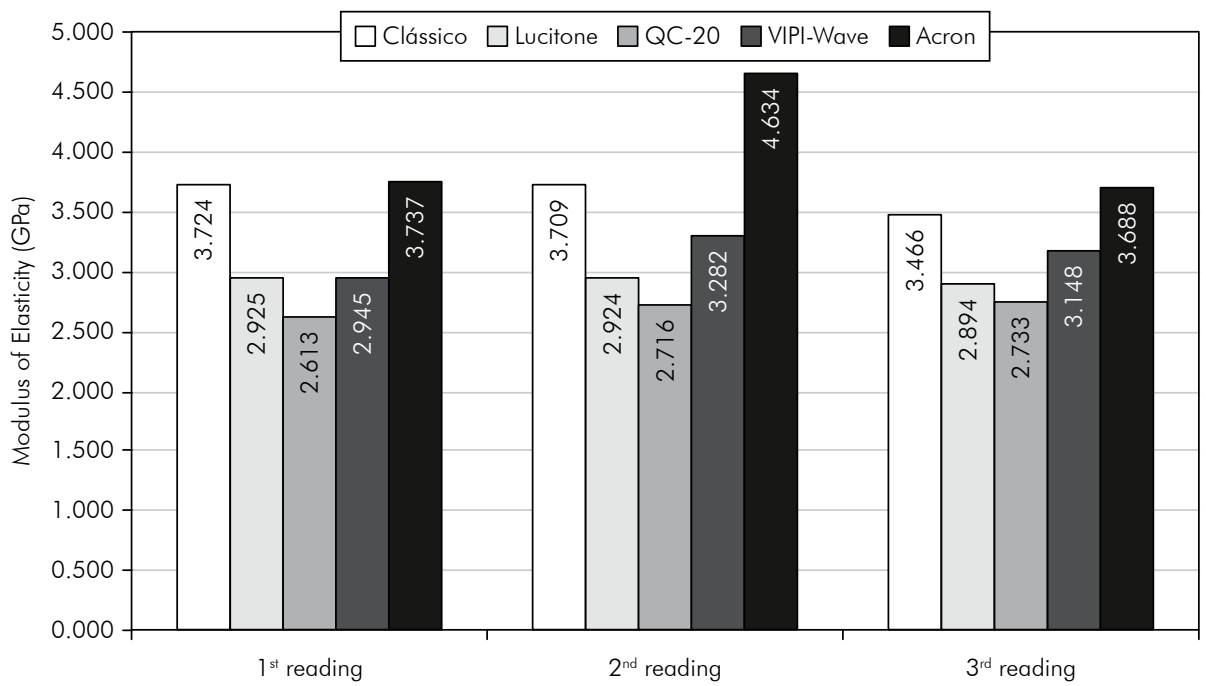

masticatory loads. In order to achieve good results, an extra effort should be made to guarantee proper manipulation of the materials.

\section{Conclusion}

The results obtained under the described conditions allow us to conclude that the Clássico ${ }^{\circledR}$ resin presented higher nanohardness values and a higher modulus of elasticity when compared to its congeners, while Acron $\mathrm{MC}^{\circledR}$ presented higher values of nanohardness and modulus of elasticity in the microwave energy polymerization group. When varying the polymerization time, only Acron $\mathrm{MC}^{\circledR}$ presented no difference when submitted to twice the polymerization time.

Regarding the behavior of the resins when submitted to a lack of humidity ( $2^{\text {nd }}$ reading) and subsequent rehydration $\left(3^{\text {rd }}\right.$ reading), the resins polymerized by microwave energy presented some hardness variations when dehydrated, specially Acron $\mathrm{MC}^{\circledR}$, when following the standard time of polymerization recommended by the manufacturer. These variations, however, diminished after rehydration.

\section{Acknowledgments}

The Nano Indenter $\mathrm{XP}^{\circledR}$ was made available by the Physics Department, Federal University of 
Paraná, Brazil. This study was approved by the Ethical Research Committee, Health Science Institute,

\section{References}

1. Bindo MJF. Estudo da dureza e do módulo de elasticidade nas superfícies de resinas acrílicas para bases de prótese total [Tese de Doutorado]. São Paulo: Faculdade de Odontologia da USP; 2003.

2. Blagojevic V, Murphy VM. Microwave polymerization of denture base materials. A comparative study. J Oral Rehabil. 1999;26(10):804-8.

3. Kimura H, Teraoka F, Ohnishi H, Saito T, Yato M. Applications of microwave for dental technique (part 1). Doughforming and curing of acrylic resins. J Osaka Univ Dent Sch. 1983;23:43-9.

4. Reitz PV, Sanders JL, Levin B. The curing of denture acrylic resins by microwave energy. Physical properties. Quintessence Int. 1985;16(8):547-51.

5. Smith LT, Powers JM, Ladd D. Mechanical properties of new denture resins polymerized by visible-light, heat and microwave energy. Int J Prosthodont. 1992;5(4):315-20.

6. Teraoka F, Takahashi J. Controlled polymerization system for fabricating precise dentures. J Prosthet Dent. 2000;83(5):51420.

7. Hayden WJ. Flexural strength of microwave-cured denture baseplates. Gen Dent. 1986;34(5):367-71.
Federal University of Paraná (UFPR), Protocol CEP/ SD: 009.SM.009/03-09.

8. Sanders JL, Levin B, Reitz PV. Porosity in denture acrylic resins cured by microwave energy. Quintessence Int. 1987;18(7):4536.

9. De Clerck JP. Microwave polymerization of acrylic resins used in dental prostheses. J Prosthet Dent. 1987;57(5):650-8.

10. Levin B, Sanders JL, Reitz PV. The use of microwave energy for processing acrylic resins. J Prosthet Dent. 1989;61(3):3813.

11. Shlosberg SR, Goodacre CJ, Munoz CA, Moore BK, Schnell RJ. Microwave energy polymerization of poly (methyl methacrylate) denture base resin. Int J Prosthodont. 1989;2(5):4538.

12. Ilbay SG, Guvener S, Alkumru HN. Processing dentures using a microwave technique. J Oral Rehabil. 1994;21(1):103-9.

13. Arima T, Murata H, Hamada T. Properties of highly crosslinked autopolymerizing reline acrylic resins. J Prosthet Dent. 1995;73(1):55-9.

14. Monteiro Netto J, Muench A, Miranda Jr WG. Influência dos tipos de polimerização na resistência transversal da resina para base de prótese total. RPG Rev Pós Grad. 1999;6(3):245-8. 